\title{
Expressive Means of Contemporary Architecture
}

\author{
Výrazové prvky současné architektury
}

Iveta Kokolia-Kř́ižová, krizova.ivet@gmail.com

Ústav teorie, Fakulta architektury, Vysoké učení technické v Brně

školitel: doc. Ing. arch. Jan Hrubý, CSc.

\begin{abstract}
In the recent years, the process of architectural design has been evolving in a number of different ways, as it has always been the case. The goal, however, remains the same - to design a quality architecture. New forms and architectural elements have also emerged with the advent of modern technologies. What are the defined facts that enter into design and reveal the boundary between high-quality architecture and mere „building“? What signs could define the current period?
\end{abstract}

KEYWORDS: functions; shape; silhouette; elements; facade; iconic architecture; context; sign

ABSTRAKT: $V$ posledních letech směřuje architektonický proces navrhování rozličnějšími cestami, něž tomu bylo doposud. Jeho cíl je ale vždy stejný. S nástupem moderních technologií také vznikají nové formy a architektonické prvky. Jak můžeme definovat skutečnosti, které vstupují do navrhování a vytvářejí hranici mezi kvalitní architekturou a stavěním? Jaké znaky by mohly vymezit současné období?

KLÍČOVÁ SLOVA: funkce; tvar; silueta; prvek; fasáda; ikonická architektura; souvislost; znak

\section{Úvod}

V posledních letech se architektonický proces navrhování ubírá vícero rozličnými 
směry, něž tomu bylo doposud. Jeho cíl je ale vždy stejný - navrhnout kvalitní architekturu.

S nástupem moderních technologií také vznikají nové formy a architektonické prvky. Kam ale tento proces směřuje? Pro malé vysvětlení se jako malé vysvětlení nám může posloužit krátké shrnutí posledních období.

Na konci 19. století bylo průmyslovou výrobou dovršeno používání ornamentů ve velké míře. Nizozemský profesor a teoretik architektury 19. století Auke van der Woud v knize Building as Ornament říká: „One would essentially purchase ornament in store." [1] (Michiel van Raaij, Building as Ornament, 2014)

V kategorickém nastolení funkcionalismu byla zavrhována veškerá historizující architektura a byl nastolen nový směr. „A tak tedy se počalo mé kázání. Řekl jsem zarmouceným:“,Utěšte se! Otevřete oči a vizte!" „Co právě tvoří velikost naší doby, jest její neschopnost vytvářeti novou ornamentiku. Přemohli jsme ornament: naučili jsme se tomu, že se bez něj obejdeme. Hle, přichází století nové, v němž se uskuteční nejkrásnějš́ pr ř́pověd. Člověk dneška uživá nebo zahazuje, podle své libovưle, ornamenty kultur starých nebo exotických. Nevynalézá již nových. Šetři a soustředuje svou vynalézavosti schopnost pro vy̌šsi věci." [2] (Adolf Loos, Řeči do prázdna: 1897-1900, 2014) V tomto období byly uplatňovány svérázné teze, u kterých se nakonec zjistilo, že reálné návrhy ne tak typicky odpovídaly psané předloze. Přes určité množství paradoxů, které všeobecně i toto období doprovázely v odkazu doby zjistíme, že se tyto prvky adaptovaly a v určitých formách přetrvávají do současnosti. Funkcionalismus zdůrazňuje plynulý a účelný provoz, funkční dispozici, která odpovídá prostorovému řešení. Vnitřní uspořádání je zvýrazněno kompozicí objemů. Následovala složitá období charakterizovaná např́ílad venkovským modernismem. Jiří Kroha své budovy komponoval z rozličně dimenzovaných objemů, kostkovitých i zaoblených, a ornamentizoval je soustavou věží, arkýřů, říms. Tyto kompozice připomínají holandský neoplasticismus 20. let, podobný dílům berlínského architekta Ericha Mendelsohna. Český funkcionalismus se ve 20. letech prosazoval velmi těžko, venkovské obecenstvo tyto strohé formy přijímalo těžce, navíc funkcionalistické stavby svými technickými nároky na provedení a údržbu bránily masovému rozšíření. Situace se změnila po roce 1930, po stavbě Veletržního palácev Praze a výstavěsoudobékulturyv Brně, kdy se za funkcionalistickou architekturu postavil český stát. Období 1948-1950 - dvouletka - bylo obdobím, kdy se poblíž dolů a továren stavěla sídliště, také vznikaly inženýrské stavby, a v tomto duchu pokračovalo stavění i v následujících letech. Panelová sídliště ovládla uniformita, skládání vyšších a bodových domů, občas doplněných zelenou plochou nebo ambicióznější veřejnou stavbou. Následoval Bruselský styl - barevná forma staveb se zkosenou nebo zakřivenou formou elementů. Později, po roce 1968, volnější formy. Brutalismus s úbytkem ideologie zapříčinil drzost a hrubost 
materiálů, siluetu stavby dotvárí drsnost povrchových materiálů. Postmodernismus: „Mladé architekty často popuzovalo, jak netvořivě a bez vtipu oficiální architektura opakuje vyčerpaná schémata mezinárodního moderního stylu, některé z nich proto přitahoval západní modernismus, jeho smysl pro humor a ironii." [3] (Michal Kohout, Česká architektura a její př́snost, Rostislav Švácha, 2004) Český postmodernismus rád přijímal masku purismu a nového funkcionalismu.

\section{Současnost}

Moderní architektura ve skutečnosti žádnou ideologii nemá, není totiž jednotná. Moderní architektura je vlastně vývojová chronologická linie. „V̌̌e nové a moderní je vše, co tu ještě nebylo." [4] (Principy moderní architektury, Christian Norberg-Schulz, 2015) Jedná se o odvržení charakterizovaných a pojmenovaných forem minulosti, obrácení se proti zaběhnutým pravidlům a figurám, odmítnutí slohů a vytvoření individualismu. Rem Koolhaas popisuje současnou na prŕkladu jakéhosi brakového prostoru: „Brakový prostor je celkovým úhrnem všeho, čeho jsme až doposud dosáhli; postavili jsme toho více než všechny předchozí generace dohromady, ale jaksi nevážime na stejné váze. My po sobě nezanecháme pyramidy. V souladu s novým evangeliem ošklivosti je na počátku 21. století už rozestavěno víc brakových prostorů, než kolik nám jich zbylo z 20. století... Vynález moderní architektury pro dvacáté století byl chybou; architektura ve dvacátém století zmizela; četli jsme pod mikroskopem poznámku pod čarou a doufali jsme, že se promění v román; zájem o masy nás učinil slepými vůči architektuře Lidu. Brakový prostor vypadá jako úchylka, ale on je podstatou, je tím hlavním... Produkt setkání eskalátoru a klimatizace, počatý v inkubátoru ze sádrokartonu (ani jednu z těchto věcí nenajdete v historických knihách)." [5] (Texty, Rem Koolhaas, 2014) Máme sílu a ambici tvořit kvalitní a hodnotné věci? Jsou opravdu současné myšlenky natolik nosné a přelomové, aby se staly součástí odkazu př́ští doby? Nebo se jen pasivně necháme unášet proudem tekoucí řeky, která zůstává ve svém korytu vymezeném technologiemi a jejich omezeními? Rem Koolhaas svým kritickým stylem ukazuje na nešvary a tíživou situaci, která však reprezentuje pouze částečný obraz současné společnosti. Jak tenká je ale ve skutečnosti hranice mezi kvalitní architekturou a „stavěním“? Máme pro ni cit, ano, někdo jistě ano. Ale budeme si jistější, když se nám podaří určit parametry, na základě kterých budeme schopni definovat rozdíly, které jednotlivá díla rozdíly, které od sebe jednotlivá díla odlišují, ale také stanovují pomyslnou stupnici, která je právě tím měřidlem kvality a společenského př́nosu.

\section{Kritéria posuzování}

Už v roce 1974 mluví Alena Šrámková o architektuře jako o výchovném prostředku, kdy je třeba oddělit potřebné od nepotřebného. Tyto teze by se daly zařadit do proudu 
minimalismu, ovšem ani já si netroufám tvrdit, že veškeré její návrhy k tomuto proudu patří. „Člověk nesmí nabírat inspiraci právě v tom, co je pokažené v širším spektru, ale prostředky dobré a poctivé architektury. Čistotou prostředí myslí Alena Šrámková čistotu architektonického návrhu." [6] (Česká architektura a její přísnost, Rostislav Švácha, 2004) V pozdějších letech se toto označení začalo užívat mnohem častěji, teoretik architektury Jiří Ševčík vyzval své přátele, aby své myšlení vyvlékli z moralistických pout. „Alenu Šrámkovou dováděla touha po prostotě a oproštění se od ismů, zbavení architektury všeho stylového a vytvoření architektury bez časového určení." [7] (Česká architektura a její př́ísnost, Rostislav Švácha, 2004) Já si kupř́ikladu myslím, že se v tomto př́ípadě nejedná o tzv. koncepční architekturu. Za architektonickým návrhem by měla stát myšlenka. Vždy je obsaženo něco, co je měřitelné a definovatelné. Architektonický koncept je koncipování a komponování architektonického díla. Je to proces, který je předmětem architektonické tvorby. Vzniká bud’ z racionální podstaty (skladebný charakter, přesná pravidla), nebo z podstaty intuitivní, která představuje uměleckou stránku. Do procesu tvorby architektonického návrhu spadá několik faktorů. Zaprvé je to zadání klienta (investora) a technicko-právní požadavky vymezující určité limity, konstrukční a částečně také typologické. Dále jsou to různá připomínkovací ŕízení dle druhu zakázky, popřípadě invence soukromého investora. Nejdůležitějším faktorem, kterým se pro specifikaci budu zabývat já, je ale vnos architekta do konkrétního díla. Bavíme-li se o tom, jak dílo vypadá, jak na nás působí, nazýváme to pojmem forma.

Rozumíme jí způsob sdělení obsahu, vnějším vyjádřením estetiky stavby je pak její výraz. Výraz je určen tvarem, velikostí, měřítkem a proporcemi, což ovlivňuje členění, velikost, propracování. Je to výtvarný způsob vyjádření dané stavby. Forma může být proměnná, $\mathrm{v}$ důsledku historie, výtvarných principů a spousty dalších faktorů, jež se budou odkazovat dále. Platnost výrazových prostředků nemusí být tedy omezena a vázána na období ani styl. Ale každá stavba je složena z několika prvků, forem, které tvoří komplexní dílo.

Pro kategorizaci je třeba stanovit objektivní stupnici pro porovnávání.

1. vztah funkce a místa - mohlo by se jednat o kontext (typické prvky, materiály, jasná reakce na genia loci)

V užším slova smyslu sem zapadá i pojem tradicionalismus.

2. vztah mezi funkcí a konstrukcí

3. vztah mezi materiálem a konstrukcí

4. vztah mezi materiálem a místem

Pro tyto kategorie můžeme dále zkoumat pojmy předních českých architektů, jako je kontextuální strategie, tradicionalismus, normálnost, regionalismus, univerzál- 
nost, umírněnost, nečasovost, autonomní architektura, racionalismus. Budeme-li se v prvotní fázi zkoumání zabývat pouhou fasádou nebo určitým detailem, nemůžeme se nikdy dostat k nějakému relevantnímu výsledku. Je třeba znát pravdu veškerá vstupní kritéria, která do návrhu byla vnesena, na základě koncepčního př́ístupu a následně je kategorizovat. Ornament může, a nemusí být př́mo ornamentem, jsou př́klady, kdy se jedná o ornament, který je potřebný k vysvětlení myšlenky a podstaty díla - v tom př́padě se jedná o jistou kontextualitu, nebo prvek nutný ke konstrukčnímu detailu. Pokud tento výskyt není nijak jinak opodstatněný, jedná se pouze o dekorativní prvek a i když je opodstatněný v konceptu autora, nejedná se o jasně kategorizující rys kontextu, ale individualismus daného autora. Individualismus reaguje na skutečnosti živým a odlišným způsobem, vyhledává i jiné abstraktní jevy, které nejsou tak snadno vysvětlitelné. Kvantifikované vědy jsou měřitelné, ale náš svět se neskládá jen z nich. Důležité jsou také lidské emoce, a tím se vytvářejí ikony.

\section{Problémy daného tématu}

I na poli českých architektů je velmi složité dostat se ke konkrétním informacím, mnoho názorů je velmi subjektivních, nebo špatně pojmenovaných a v konkrétních př́ípadech výzkumu bude třeba oslovit dané architekty a podrobit je strukturovanému rozhovoru.

Příspěvek vznikl ve vazbě na výzkumný projektu FA-S-16-3727 - 100. výročí vzdělávání architektů na Fakultě architektury VUT v Brně, oblast architektura.

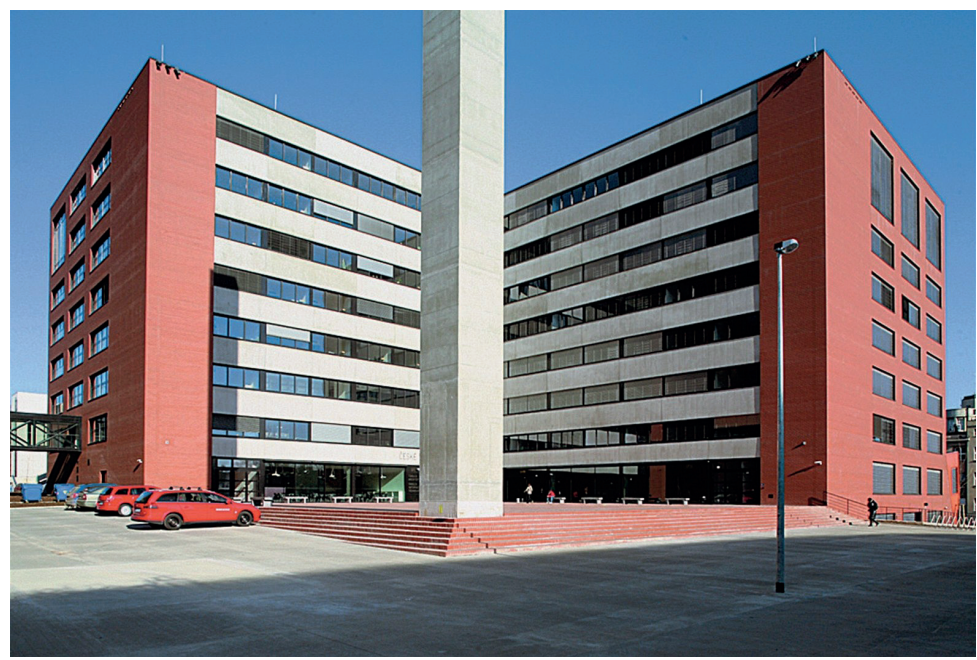

Obr. 1. ČVUT, nevýrazovost, Alena Šrámková. 


\section{Prameny}

KOOLHAAS, Rem, TICHÁ, Jana, ed. Texty. Praha: Zlatý řez, 2014. Čtení o architektuře. ISBN 978-80-903826-8-8.

LOOS, Adolf. Řeči do prázdna: 1897-1900. Hodkovičky [Praha]: Pragma, c2014. ISBN 9788073494049.

NORBERG-SCHULZ, Christian. Principy moderní architektury. Přeložil Lubomír KOTAČKA. Praha: Malvern, 2015. ISBN 978-80-7530-032-4.

RAAIJ, Michiel van a Charles FRINK. Building as ornament: iconography in contemporary architecture. ISBN 978-946-2080-447.

ŠVÁCHA, Rostislav. Česká architektura a její př́ínost: padesát staveb 1989-2004. Praha: Prostor - architektura, interiér, design, 2004. ISBN 80-903257-3-4.

\section{Seznam vyobrazení}

Obr. 1. [online]. In: . [cit. 2017-10-08]. Dostupné z: https://praha.idnes.cz/foto. aspx? $r=$ praha-zpravy\&c=A130702_1947310_praha-zpravy_sfo $\&$ foto=AB3ddd84_7652997_jpg_2_.JPG

Obr. 2. [online]. In: . [cit. 2017-10-08]. Dostupné z: https://www.mimoa.eu/ images/1028_l.jpg

Obr. 3. [online]. In: . [cit. 2017-10-08]. Dostupné z: [online]. In: . [cit. 2017-10-08]. Dostupné z: http://www.designmagazin.cz/foto/2016/12/kuba-pilar-knihovna-filozoficka-fakulta-brno-0.jpg

Obr. 4. [online]. In: . [cit. 2017-10-08]. Dostupné z: http://www.sepka-architekti.cz/ DataBic/Library/Images/Full_060/848cc012b82e2bdcaf0124e2840efb86_017.jpg

Obr. 5. [online]. In: . [cit. 2017-10-08]. Dostupné z: http://www.ex-centric.eu/cs/galerie/modlitebna-cirkve-bratrske-v-cernosicich?type $=$ foto

Obr. 6. [online]. In: . [cit. 2017-10-08]. Dostupné z: http://www.stavbaroku.cz/db_ image/site_large/4499.jpg

Obr. 7. [online]. In: . [cit. 2017-10-08]. Dostupné z: http://www.pelcak.cz/projekty/ obytny-soubor-pod-palackeho-vrchem-brno/ 


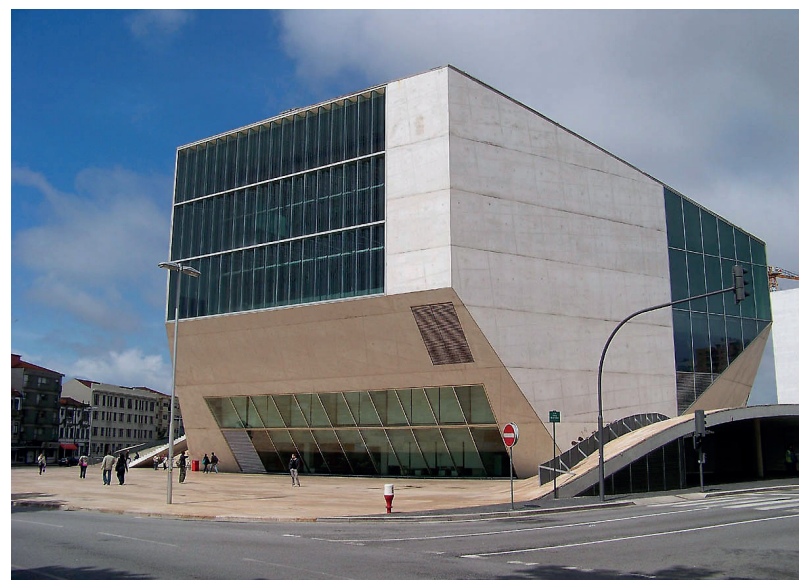

Obr. 2. Casa da Musical, individualismus, Rem Koolhaas

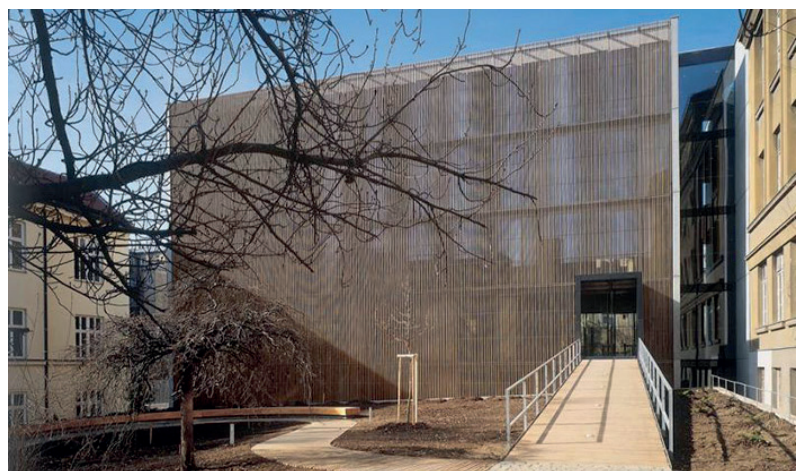

Obr. 3. Ústřední knihovna FF MU Brno, druhá moderna, Kuba, Pilař

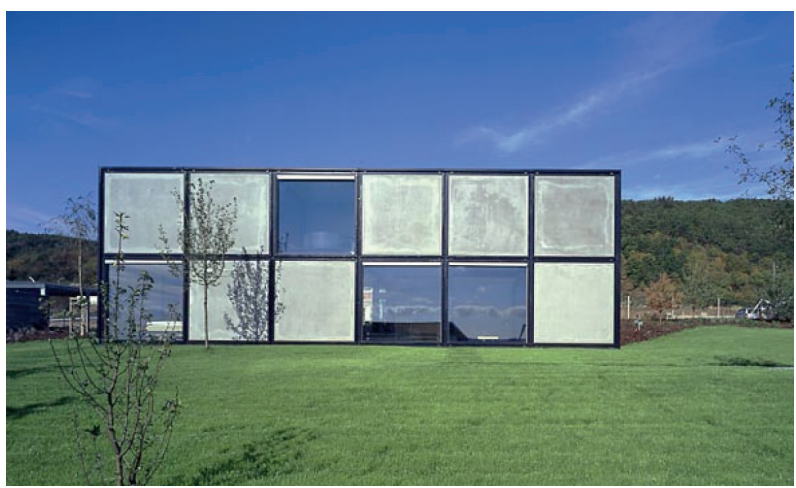

Obr. 4. Vila v Berouně, technologická pravdivost, HŠH 


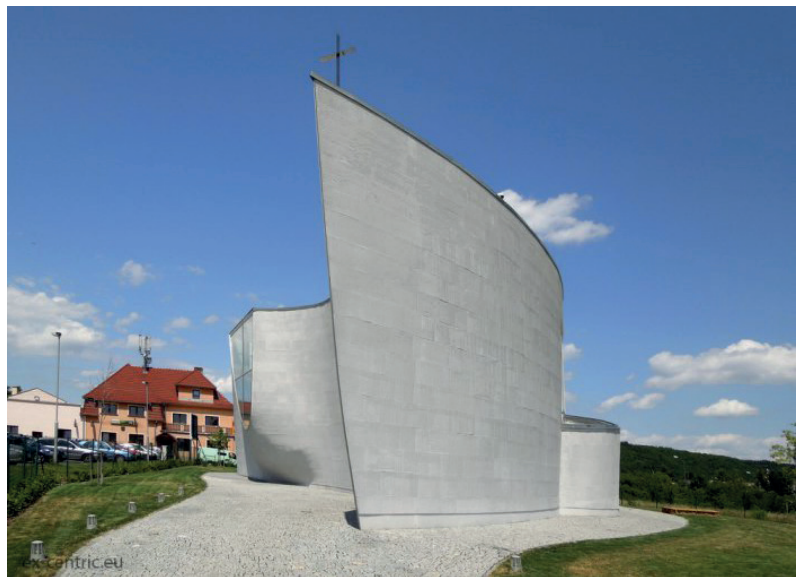

Obr. 5. Modlitebna Církve bratrské v Černošicích, plastická forma, Zdeněk Fránek

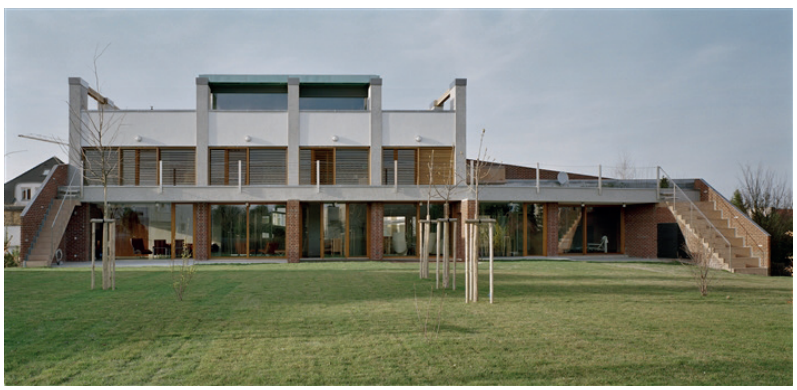

Obr. 6. Vila v Břevnově, regionalismus, kontextualita, Ladislav Lábus

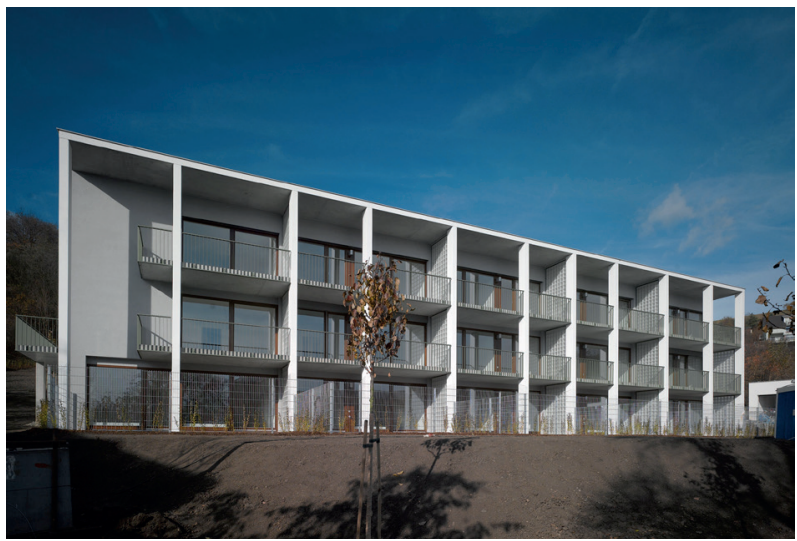

Obr. 7. Obytný soubor pod Palackého vrchem Brno,materiálový minimalismus, Petr Pelčák 